InOedia $\begin{aligned} & \text { InMedia } \\ & \text { The French Journal of Media Studies }\end{aligned}$

9.1. $\mid 2021$

Film and TV-induced Tourism: Some Contemporary

Aspects and Perspectives

\title{
Gazing without risks. How to experience Italy, in the tourism industry interpretation of the film The Great Beauty
}

Giulia Lavarone

\section{OpenEdition}

\section{Journals}

Electronic version

URL: https://journals.openedition.org/inmedia/2955

DOI: 10.4000/inmedia.2955

ISSN: 2259-4728

Publisher

Center for Research on the English-Speaking World (CREW)

Electronic reference

Giulia Lavarone, "Gazing without risks. How to experience Italy, in the tourism industry interpretation of the film The Great Beauty", InMedia [Online], 9.1. | 2021, Online since 15 January 2022, connection on 08 February 2022. URL: http://journals.openedition.org/inmedia/2955 ; DOI: https://doi.org/10.4000/ inmedia. 2955

This text was automatically generated on 8 February 2022.

(C) InMedia 


\title{
Gazing without risks. How to experience Italy, in the tourism industry interpretation of the film The Great Beauty
}

\author{
Giulia Lavarone
}

1 The role played by the media in shaping the "tourist gaze" has been widely explored in the last twenty years. As John Urry and Jonas Larsen state, "it is virtually impossible to visit places which people have not traveled to 'imaginatively' at some time." ${ }^{1}$ The potential of films and TV series to induce tourist flows has been extensively acknowledged, leading the film and tourist industries to collaborate frequently to promote both films and places, and to create new tourist products. In her influential work discussing the alliances between these "global sign industries", Rodanthi Tzanelli highlights that "central to the operative forces of these industries is a game of endless hermeneutics: by filmmakers (of novels on which films are based), by audiences (of films) and by holiday providers (of audiences' film readings)." ${ }^{2}$ The main focus of this study is the tourist industry's "hermeneutic" acts, which involve issues concerning heritage, and national and local identities, implicated in the film itself and variously interpreted by audiences, film critics, the tourism industry and by film tourists themselves. In this paper, ${ }^{3}$ I will explore how Italian heritage is presented through the narrative and stylistic features of the Academy Award-winning Italian film The Great Beauty ( $L a$ grande bellezza) by Paolo Sorrentino (2013), and the ways in which to experience Italy that are suggested by the tourism industry through its interpretation of the movie. The Great Beauty has been widely discussed by Italian and international film scholars, as well as by the national press, in relation to the role of movies in shaping the (foreign) tourist gaze on Italian heritage, but the analysis has always been limited to the film text, never exploring its use in official tourist marketing and/or in the creation of tourist products. ${ }^{4}$ 
2 I will start with a brief introductory section on the connections between heritage, tourism, and film, paying attention to the interpretive role of tourism marketing, whilst recalling the concept of "heritage film". I will then trace some arguments of the national debate on The Great Beauty as a film designed for a tourist gaze and I will draw an analysis of textual elements that explicitly invite to a tourist reading. In this section, I will rely on previous understandings of The Great Beauty as a heritage film questioning which heritage it displays. Finally, I will examine what kind of tourist experience is proposed in relation to the film by public and private tourist marketing through a survey of the online tourism marketing pages set up by public bodies and by private operators selling movie tours. The tourists' own interpretations of this marketing will not be explored in this paper, yet they could provide a subject for future research.

\section{Heritage, film and the interpretation of tourism marketing}

3 The phenomenon of actual tourist visits induced by media, the so-called "film-induced tourism", "film tourism", "mediatourism", "screen tourism" or "media pilgrimages", has been broadly discussed by academic research within several disciplinary fields, from tourism management to cultural geography, media and fan studies. ${ }^{5}$ Explorations on the on-site experiences of film tourists led by scholars like, among others, Anne Buchmann, Sangkyun Kim, Stefan Roesch and Stijn Reijnders, often highlight their existential value, clearly exceeding a cognitive dimension and frequently entailing forms of identification with movie characters, pursued through mental simulations, and sometimes resulting in physical re-enactments. ${ }^{6}$ While recognizing the undeniable relevance of gaze within these experiences, studies also stress the strong involvement of other senses, often solicited by the design of the tours provided by private operators (e.g., listening to the film soundtrack, tasting food, or handling objects connected to the movies). These multisensorial stimulations contribute, along with social interactions with the guide and other tour participants, to help tourists to remain satisfactorily "immersed" in the experience. ${ }^{7}$

4 Virtual travel occurring through movie-watching is also included by Urry and other theorists among the experiences of the contemporary "post-tourist." ${ }^{\text {" While surveys }}$ adopting tourism economics and management perspectives often aim to identify the influence of movies in the actual purchase of tourist products, ${ }^{9}$ media studies are also interested in exploring "tourist imagination", intended as "the imaginative investment involved in the crossing of certain virtual boundaries within the media or actual boundaries within the physical process of tourism." ${ }^{10}$ Within this theoretical framework, including both physical and virtual tourism (even if not conflating them), Rodanthi Tzanelli identifies four variously interconnected definitions of the "cinematic tourist." The first one is the ideal tourist existing within movies themselves, which present different modes of tourist consumption of places. The second and third ones are virtual tourists, travelling through the very act of watching the movie or through eventually surfing on the Internet, accessing websites concerning the portrayed locations. This happens when the tourist industry enters the game and movie locations become tourist products. Finally, there is the cinematic tourist physically visiting movie locations..$^{11}$ Les Roberts suggests a fifth understanding of the "cinematic tourist" in relation to tourist flows being encouraged not only by the tourist industry, but also 
by the film industry, which now actively collaborates to destination marketing campaigns. ${ }^{12}$

The connection between the heritage industry, understood as part of the larger leisure and tourism sector, and the specific genre of costume films, was described by Andrew Higson in his discussion of "heritage films" made in Great Britain since the 1980s. This production trend, on one hand, depicts a selected English heritage to the benefit of a mainly American public in the ways that heritage bodies traditionally imagine the country, and on the other hand, naturally becomes the ideal subject for film tourism marketing. In this context, the film and the tourism industries share common goals and logics, with films often adopting an "aesthetics of display" and heavily relying on heritage elements-used as "attractions" in Tom Gunning's sense ${ }^{13}$-counting more in the movies than the development of tight narratives. ${ }^{14}$ Obviously, besides the movies themselves, tourist marketing also plays a key role in shaping the tourist gaze and in identifying, and interpreting, a selected heritage to the benefit of film tourists. The tourist industries provide specific interpretations of audiovisual texts and, jointly, of the places therein portrayed. As an example, Visit Britain's movie maps are usually developed around a leitmotiv, i.e., a theme considered to be key in the film narrative and used to design themed itineraries throughout the country. ${ }^{15}$ These destination marketing tools and campaigns can also be inspected to identify which and whose heritage they select and promote. Roberts, for example, points out that the Movie Map North Wales indicates the locations of several high-production movies but excludes films shot in Welsh language, ${ }^{16}$ while Tzanelli understands tourism marketing related to Game of Thrones in Northern Ireland as a re-interpretation of the country's "thanatic heritage matrix" at the core of the consolidated dark tourism phenomena related to civil war and terrorism in the region. Tzanelli highlights Game of Thrones' "potential to hybridise Ireland's traumatic memories of civil war," due to the specificities of its plot largely displaying familiar feuds, which thus allows these "hermeneutic cycles" to take place. ${ }^{17}$

6 The texts produced for tourist marketing, both by public bodies and by private operators, will be here understood as potential paratexts ${ }^{18}$ that carry specific readings of the film text within the peculiar context of reception represented by the cinematic tourist experience, either actual or virtual (i.e., through web surfing). ${ }^{19}$ This kind of exploration is particularly new to the Italian context, where film tourism is still barely considered in the field of film studies, while the main contributions belong to the disciplinary field of cultural geography or, to a lesser extent, tourism management. ${ }^{20}$ Italian film studies have dealt with the connection between film and tourism mainly analyzing the role of films as historical documents that portray tourist practices in different times. Recently, the focus has also been on the new modes of film production, involving regional film commissions as funders, and on their influence on the film texts, portraying landscapes previously unseen yet accused of proposing an aesthetics more suited to commercials. ${ }^{21}$ Almost no interest has been paid to the aftermath of film production, namely to the use of movies for tourist marketing and for the devise of tourist products, as well as to the experiences of film tourists. This is patent in relation to the emblematic case of The Great Beauty, as mentioned in the introduction, considering its relevance in the debate on film and tourism in the Italian context. 


\section{Gazing at the Great Beauty of Italian heritage}

7 The aforementioned concept of heritage film can be considered extremely useful well beyond British borders, to be employed "heuristically" in relation to other European and global contexts, "all of which inflect the specific concept of heritage they seek to communicate." ${ }^{22}$ As regards the Italian context, Rosalind Galt has termed as heritage films a series of works released between the 1980s and 1990s, such as Cinema Paradiso (Nuovo Cinema Paradiso, Giuseppe Tornatore, 1988), Mediterraneo (Gabriele Salvatores, 1991) and The Postman (Il postino, Michael Radford, 1994). All of these films are historical narratives set during or immediately after World War II and they seem to share a common will to display Italian and Mediterranean beauty, identified in a mix of attractive natural landscapes and female bodies. ${ }^{23}$ For these reasons, they are suspected to have "been designed for a foreign tourist gaze and therefore to commodify the country's appeal as a kind of 'Brand Italy' for the Anglophone market," also in relation to their distribution by Miramax in the United States. ${ }^{24}$ In recent times, Galt and Karl Schoonover have conveniently labelled the Ivory screen-written transnational production Call me by your name (Luca Guadagnino, 2018) a heritage film: it is set in the 1980s, generously displaying Italian natural and cultural heritage..$^{25}$ slightly more surprisingly, The Great Beauty as well has been discussed in terms of heritage film.

8 The Great Beauty premiered at the Cannes Film Festival in 2013, where it did not receive any award. It subsequently won the Academy Award for Best Foreign Language Picture in 2014 and was released in almost forty countries, gaining more than half of its total gross outside Italy. If we consider only the Italian, European and American takings, it is possible to notice a much greater relevance of the European market compared to the American one (Italian takings $41 \%$ of the total; European, $47 \%$; American 12\%). Despite that, The Great Beauty was the second top Italian film for admissions in the US in the period 2008-2017, surpassed only by I am love (Io sono l'amore) by Luca Guadagnino, released in the US in 2009. The film has been widely appreciated by foreign critics and is often included within the syllabi of Italian cinema courses in foreign universities. ${ }^{26}$

Besides its international circulation, which was broad if compared to most Italian productions and co-productions, the reasons for its relevance lay in its critical reception in Italy, which traces a field of tensions concerning issues of national identity. In part, Italian reception has been positive or even enthusiastic, praising the Academy Award winner as a source of national pride. However, in most cases, the film has been harshly criticized, with the accusation of having been expressly 'packaged' in order to promote an 'Italian brand' to be consumed abroad. According to detractors, this was done through an excessive display of Roman heritage and an (ab)use of stereotypes on Italy and Italians to appeal to foreign audiences. These accusations frequently mentioned the film's explicit and pervasive reference to the model of Federico Fellini's La dolce vita (1960), which is a 'must' when referring to Italian auteur cinema abroad and showcases an iconic image of Italy and of Rome. Sorrentino has often been accused of having re-proposed this model outwardly and without genuine inspiration, just as part of a highly recognizable 'Italian brand. ${ }^{27}$ As an example of this critical approach to the movie, I will only mention the revealing titles of some articles, published in one of the main Italian journals devoted to cinematographic culture, Cineforum. In July 2013, the journal featured an ensemble of articles, whose topics ranged from "Rome in postcard" (Roma in cartolina) to "Rome: this must be the 
(product) place(ment)," both titles explicitly accusing the film of being produced for tourist purposes. ${ }^{28}$ It can be added that among the sources used for financing the film, there is also the film fund of the Lazio region where Rome is set. It is well-known that the first goal of regional financing is connected to the direct expenses made on-site for film production, and to the involvement of local audiovisual professionals, yet some attention is also paid to the tourist exposure of the territory. ${ }^{29}$

It is not surprising then, that regardless of the film's contemporary setting which differs from the historical one usually associated with heritage films, Alain O'Leary states: "La grande bellezza very obviously proposes itself as a heritage film, with sumptuous tracking shots along the streets of Rome's old centre and 'privileged' access to the historical edifices and gardens of the city granted to us". ${ }^{30}$ First of all, besides the choice of outstanding locations, Sorrentino's distinctive style luxuriously amplifies the "aesthetics of display" and the attractional power of heritage identified by Higson as defining traits of heritage films. Secondly, the narrative of The Great Beauty lends itself to an explicit tourist reading since the very beginning, suggesting modes of tourist consumption by staging different kinds of "cinematic tourists", namely ideal tourists existing within the film text. At the beginning of the movie, the Japanese tourist is caught in the classic tourist act of taking photographs, he has just moved away from a (presumably standardized) group visit by bus and is fatally exposed to Rome's unbearable beauty. His death stands as a symbolic ritual of killing the (mass) tourist hidden in any of The Great Beauty spectators, to whom the film promises to offer a much more exclusive and unique experience of the city. The guide, Jep Gambardella (Toni Servillo), is a former outsider, just like the character of Marcello (Marcello Mastroianni) in La dolce vita and like Fellini and Sorrentino, born in Rimini and Naples respectively. Nevertheless, he has become the most expert insider among the insiders, maybe fulfilling the secret desire of many tourists. Thanks to his personal connection with Stefano (Giorgio Pasotti), the keeper of the secret keys, he can reveal the hidden gems of Rome to other characters and spectators, that even Roman people, like his friend Ramona (Sabrina Ferilli), whose name is as an anagram of Romana (feminine inhabitant of Rome), do not know-or, at least, cannot visit alone at night. In the scene of the nocturnal tour, Ramona thus becomes a second "cinematic tourist" within the movie, contrasted to the Japanese tourists of the opening scene. The sumptuous palaces of Roman decaying aristocracy are on display here-a specific kind of heritage which is normally not accessible to lower social classes. Anyway, even when the featured monuments are within everyone's reach, and have no doors to unlock, the uniqueness of the tourist experience while watching The Great Beauty is conveyed by Sorrentino's style, which offers the spectator unprecedented views of well-known Roman attractions, like the Tempietto built by the famous architect Bramante. For this monument and for many others, such as the Fontanone at the beginning, Sorrentino inserts at least one shot that clearly shows the monument in its entirety, among others characterized by ample camera movements and through bizarre camera angles. The ancient and the Renaissance heritages are the subject of this amazed gaze, while contemporary art performances are sometimes looked at with a suspicious eye, from the derision of the artist Talia Concept to the forced exhibition of the child artist. Only the nostalgia-filled photographic installation in Villa Giulia, which does not efface a past irremediably lost but celebrates it with a heart-breaking nostalgic mood, deserves the same amazed treatment of Renaissance and ancient heritage. Significantly, this scene which according to the screenplay should have been set in the MAXXI Museum of 
contemporary art, was finally shot in the $16^{\text {th }}$ century building Villa Giulia, which hosts the museum of Etruscan art.

11 Less evident, yet pervasive, is the presence of a sort of modern Italian heritage: the $20^{\text {th }}$ century 'Made in Italy' brand. This is epitomized by Martini, the brand that stands out on the large billboard, clearly visible during the party scene. Interestingly, Martini's and Peroni's appearances are not product placements. These and other similar brands, selected to appear in the film, are considered old-fashioned in Italy yet still epitomize Made in Italy abroad. ${ }^{31}$ They thus become the subject of the same "nostalgic gaze" devoted to ancient and Renaissance heritage, a type of gaze which, according to Higson, characterizes heritage films, and "resists the ironies and social critiques so often suggested narratively by these films". ${ }^{32}$ According to Andrea Minuz, Sorrentino's film is emblematic of the tight connection between Made in Italy and the construction of Italian identity. This identity is described by Minuz as "fragile," built for the purpose of a "tourist gaze," and relying on a sort of "aesthetic primacy granted [to Italy] by foreign gaze." Bellezza (beauty) can be considered in Italy as a "mythical figure, national mission and obsession." ${ }^{33}$

To use Stephen Gundle's words, we could say that Sorrentino's film draws both from the "traditional" and from the "modern" Italian brand. According to Gundle, the first should be identified in the Grand Tour traditional image, portraying Italy as the country of an ancient civilization, Renaissance art and architecture, natural beauty, and a certain way of life, including elements of violence and sex. The modern brand instead originated after the Italian unification (1861), especially with $20^{\text {th }}$ century fascism and the post-war economic development, and it is related to-for examplecars, design, fashion, food, and tourism..$^{34}$

"Part of the [modern] heritage on display" ${ }^{35}$ in Sorrentino's film, through pervasive intertextual references, is also Italian auteur cinema of the 1960s, including La dolce vita, which indisputably takes part in the Italian brand abroad. Via Veneto, the most famous of Fellini's locations, appears in Sorrentino's film and becomes the subject of its typical nostalgic gaze. Via Veneto is shown as a place nowadays deserted by Romans and only frequented by international tourists. Its appearance thus provides an additional argument in the film's discourse on (mass) tourism. Incidentally, Fellini's film itself has been accused of sharing some responsibilities in the transformation of via Veneto into a tourist spot. La dolce vita epitomizes the historical moment when, according to Gundle, "Roman glamour became Italian glamour for the world." Having become famous abroad as "the city of sin and pleasure,"

Swinging Rome was not just classy but also dangerous in the popular imagination. The surface style and the bright, figure-hugging Brioni men's suits that preceded the flair of London and that featured in so many foreign television films and series of the period mixed stylishness with decadence and corruption. Italian glamour combined sex and style for foreigners. Italy became an image to be consumed, to be bought into, and to be savored in small doses, by means of a film, a vacation, a meal in a restaurant, an item of clothing, or a domestic appliance. ${ }^{36}$

14 In her book on the tourist imaginary of Italy, Stephanie Malia Hom also highlights the role of Fellini's film in shaping and communicating this imaginary, especially in relation to the trope of dolce vita ("the sweet art of life"), framing Italy "not only as a land of leisure but also as one of sensual excess." According to Hom, dolce vita is often combined with another persistent trope, that of il dolce far niente ("the sweet art of idleness"). The topos of il bel paese instead, identifying "the beautiful country" full of 
artworks and ruins, established by the Grand Tour tradition, "marks Italy as an aesthetic space rather than a leisure space," often emphasizing the role of sight over other senses. The country is imagined as substantially "pre-modern," with no relation to present times. ${ }^{37}$ Sorrentino's film generously picks up on these consolidated stereotypes, which can be seen as outlining a sort of 'Italianism,' or even of 'Romanism.' These two terms might sometimes be used interchangeably when referring to foreign interpreters, but the second is obviously more appropriate when we think of Italian tourists addressed by tourist proposals, drawing on a representation of Rome based on another seducing common topos-that of decadence. Rome is shown as a magnificent capital of an ancient Empire which has gradually slipped into fatal idleness-a controversial 'archaeology of decadence' that is implicitly traced by the same Fellini's filmography, including a famous adaptation of Petronius' Satyricon (1969).

As O'Leary suggests, relying on a previous study by Daniele Balicco, La grande bellezza should be thought of as an "ambivalent text" because, "while it confirms the most banal (and therefore paradoxically reassuring) reading of Italy's decline, it contradicts this reading in the form it adopts, playing explicitly with the contrary but just as powerful symbolic image of Italy as an enchanted wonderland." 38 O'Leary's discussion of The Great Beauty as heritage film actually rests on the consideration that ambivalence is a "defining characteristic" of heritage films, because "no heritage film is without its commentary (more or less controversial) on politics and the past, but the packaging of history as heritage implies its presentation for a tourist gaze." ${ }^{39}$ This ambivalent trait is explicitly brought out by the tourism industry, which provides an interpretation of the film that conceals any critical reference to contemporary Italian life, as I will highlight in the next section.

\section{The Great Beauty read by the tourism industry}

It is rather obvious that the influence of The Great Beauty on tourism would not be easy to quantify, as it is related to the role played by (relatively) popular films in the building of destination image in the long term. This paper will not deal with measurement issues, yet it might be argued that the easiest variable to identify in the short term would be the possible increase in the number of visitors to the single movie locations, especially those which regulated access with entry tickets. Unfortunately, in some cases the institutions that manage them are not allowed to make their data available to the public, while in other situations, the managers of heritage attractions contacted during this research felt the number of visitors had increased yet have not collected data to support their claim..$^{40}$ In any case, the influence of The Great Beauty on Roman tourism clearly goes beyond the visit to actual movie locations. Roman tourism marketing in general seems to have taken advantage of the film's captivating title in various ways, exactly as it happened with La dolce vita in the 1960 s. ${ }^{41}$ Single hotels use the expression great beauty on their websites, and the same appropriation is made by tour operators which sometimes offer tours of Rome with this name, although having no connection to the film.

The modes of tourist consumption suggested by the online public and private tourist marketing related to The Great Beauty will be explored here. These modes involve the third type of "cinematic tourist" identified by Tzanelli, i.e., those searching the web for more information about movie locations (even if cinematic tourists who are physically 
on-site might also use these resources). A manual content analysis was conducted on the textual and visual online presentations of Great Beauty itineraries within the official tourist promotion websites of the city of Rome and of the Lazio Region and within the websites of private tour operators selling 20 different The Great Beauty-inspired tours, provided in English. ${ }^{42}$ When the same tours were offered in Italian language, the English and the Italian textual and visual presentations were compared to spot possible differences. Information was gathered about the design of the tours, concerning respectively: the chosen landmarks, the length, the price, the means of transportation and the proposed experiences. Finally, some data was collected about the average number of tour participants, while an in-depth phone interview was conducted with the only operator that is specialized in movie tourism. ${ }^{43}$

The survey was carried out in May 2018, exactly 5 years after the film's premiere at the Cannes Film Festival (May 2013) and almost 4 years after the Academy Award ceremony (March 2014). This has allowed us to explore the persistence of tourist proposals expressly related to the film.

The analysis started from three questions. The first one originated from existing literature on the on-site experiences of film tourists participating in movie tours: which activities are proposed, and which behaviors are suggested-through images and texts-to solicit an emotional identification with The Great Beauty's characters and atmosphere, and create an immersive experience and/or stimulate senses other than sight? The second one was derived from the specific disciplinary perspective of film studies and the textual analysis of the movie, identifying its portrayal of ideal tourists. Is this meta-tourist reading of the film used in any way by the images and texts created for public and private tourist marketing? The third one originated again from a film studies perspective, dealing with the national and international reception of the film, extensively revolving around its connections to La dolce vita. This perspective was linked to findings on Italy's image as a tourist destination and on the contribution of Fellini's film to shaping and spreading some topoi, especially that of the eponymous la dolce vita and the inherently related il dolce far niente. Are there any textual or visual references to Fellini's movie? And are there any textual or visual clues signaling the touristic imaginary of Italy as the country of dolce vita and il dolce far niente, and/or any invitations to "sensually" experience it? Finally, are there any references to the topos of Roman decadence, proposed by Sorrentino's movie after Fellini's model?

Starting from marketing materials devised by public bodies, the official tourist promotion websites of the Lazio Region (VisitLazio) and of the city of Rome (TurismoRoma) both set up a page related to the film, each website suggesting their own itinerary to tourists. A distinctive element of the text presenting the itinerary on the regional website is the strong reference to the topos of Roman decadence, which is evoked in the beginning and also later, when talking about the Coliseum:

Oscar for the Best Foreign Language Film, "The Great Beauty" directed by Paolo Sorrentino was filmed entirely in the palazzos, terraces, famous and hidden gardens in a Rome that is decadent, jaded and gorgeous. (...) The last stop is at the protagonist's house with its exclusive and close-up view of the Coliseum. (...) This is undoubtedly the best perspective there is to enjoy a view of the Coliseum, symbol of all that is Rome in its magnificence and deep wounds.

21 I would like to dwell more on the page of TurismoRoma, titled Discovering "The Great Beauty. " ${ }^{\prime 4}$ Here the itinerary is interestingly signed by Costantino d'Orazio, a wellknown art history popularizer often appearing on TV and a writer of art books. 
D'Orazio has authored the volume La Roma Segreta del film La Grande Bellezza (The Secret Rome of the film The Great Beauty), published in 2014 in Italian and in English with the title The Great Beauty of Rome. D'Orazio's involvement is not surprising, if we consider that some of his works are conceived as guidebooks to places which normally are not accessible to the public, like Le chiavi per aprire 99 luoghi segreti di Roma (The keys to open 99 secret places in Rome) and Le chiavi per aprire 99 luoghi segreti d'Italia (The keys to open 99 secret places in Italy), both published in 2011. These titles strongly resonate with the scene of the keys in The Great Beauty, released two years later, and D'Orazio himself in his book on the film highlights the coincidence. His subsequent book Andare per ville $e$ palazzi (Hanging out at villas and palaces, 2015), significantly chooses heritage linked to the past of aristocracy, also privileged by The Great Beauty. The book on The Great Beauty is analogous to the others and should not be properly considered as a classic movie location guide, as the film appears as a pretext to offer descriptive pages on places which normally are not easily accessible. Even places that do not feature in the film, yet are adjacent and considered worth a visit, are fully described (e.g., the Salone dei Mappamondi in Palazzo Sacchetti). ${ }^{45}$

The official tourism marketing page on the TurismoRoma website, relying on D'Orazio's approach, thus adopts the meta-tourist reading of The Great Beauty suggested by some scenes of the film itself, especially that of the keys. Film tourism is seen here as an alternative form of urban heritage tourism, allowing for the creation of new tourist products through the interpretation of heritage in unprecedented ways. ${ }^{46}$ The interest of this approach, suggested by the film itself, is explicitly identified by official tourism marketing in its "non-mass tourism" status, as the beginning of the text written by D'Orazio on the TurismoRoma webpage immediately suggests:

"The Great Beauty" shows us more of Rome than we find in the postcard versions. It explores the hidden corners, behind doorways and gates that never seem to open. But even these places, apparently beyond our reach, can be visited! This guide tells you how you can experience Rome the way you might on a film set. ${ }^{47}$

As regards the tours offered by private operators, their length varies from 3 to 8 hours, with only one tour lasting several days. The declared prices for half-day or one-day tours vary within a large range, from 50/70 euros (only one costs less, i.e., 18 euros) to almost 1,300 euros, depending on whether it is a private or group tour, and on the means of transportation. The latter are varied: from walking, to segways, electric bikes, golf carts, minivans, passing through the typical Italian Vespa or Fiat 500 and luxury solutions such as Limousines or Mercedes cars. Comparing the locations selected for the different tours, two relevant observations can be made. First, in some cases the absence of locations that, while less attractive, are extremely important in the narrative (e.g., the protagonist's house), reveals how the film is sometimes only used to devise alternative heritage tourist products, with no particular interest for its diegesis. Second, the preference, in most cases, for locations linked to "traditional" rather than "modern" heritage is patent (e.g., the Salone delle Fontane, in the modern district of Eur, is rarely present in the tours).

As the aim of this research was to explore the tourism industry's interpretation of the film, no survey has been systematically conducted on the actual bookings of the tours. However, several tour operators were asked for data and only two positively answered, albeit providing estimates because they had not kept trace of the exact number of bookings. The information is too poor to draw any general conclusions, yet it must be said that both operators announced limited bookings. In the perspective of this paper, 
the different readings of these limited numbers carried out by the two operators are interesting. While one complains about what he considers a highly unsatisfying result (about 10 bookings in 5 years) and ascribes it to a scarce distribution and knowledge of the film abroad, the second, specialized in movie tourism, considers the results satisfying with about $13 / 14$ bookings per year. The same operator is nonetheless used to attaining a much higher number of bookings for tours related to other films. As an example, for the tours dedicated to Angels \& Demons by Ron Howard, the operator in 2018 (nine years after the film release in 2009) reported that the number of bookings is almost constant and amounts to around 500 per year. His satisfaction about the comparatively poor results of The Great Beauty tour is due to a clear identification of its very specific target, highly cultured foreign tourists, and of the main feature of the tour - precisely its exclusiveness. ${ }^{48}$

Not by chance, most of the tours under examination are private tours for pre-defined groups. Only 6 out of 20 are group tours based on individual bookings. In the case of private tours, the rhetoric of the promotion of lesser-known and not easily accessible places, differing from those traditionally attracting mass tourism, adopted by the official tourism marketing, easily transforms into a rhetoric of exclusivity. It is evident that the choice of offering private tours is partly forced in the case of a "difficult" film like Sorrentino's, and even more so in Italy, where film tourism mostly consists in private tours, because of the tightness of this market in the country. Interestingly, in the case of The Great Beauty, the meta-tourist reading of the film allows the transformation of this limit into an additional value, as this exclusive experience is contrasted with that of mass tourism: "Experience the real Rome away from the traffic and tourist traps." ${ }^{49}$

The "experience" to which most of the texts and images refer to is, nevertheless, limited to the sense of sight and to visual pleasure. Through adopting the meta-tourist reading, almost all of the tour descriptions emphasize the possibility of visiting secret places and/or experiencing unusual views and perspectives. Here is an example of one tour, whose listed "highlights" include the exploration of "the movie's most magical and secret places":

From the house of Jep Gambardella, wonderful penthouse in Colosseum's Square, we continue to the Aventine Hill to peek Saint Peter's dome by an unusual look. How [sic] the director Sorrentino, we will explore the most famous places of the Gianicolo: the Fountain of the Acqua Paola surmounting the complex of San Pietro in Montorio, with the Temple of Bramante.

We will admire the skyline from the terrace of the Orange Garden, one of the most picturesque and magic place [sic] of the city.

We'll enjoy the Galleria Spada, where we admire [sic] the masterpiece of "trompe l'oeil," the false perspective of Borromini.

The last leg of the tour the artistic scenery of the Park of the Aqueducts, in the are [sic] of Quadraro, Cinecittà, Porta Furba and is one of the most beautiful green spaces and evocative of the city..$^{50}$

Emphasis is mainly laid on the sense of sight and the possibility to enjoy amazing panoramas. In most of the texts, the only action solicited is that of taking photographs, thus the only solicited identification is not with the main characters but with the Japanese tourist of the beginning, even overcoming the embarrassment caused by his death, which obviously is never alluded to. A tension is always at work in the textual presentations between the guarantee to the tourist that he/she will "collect" famous landmarks and the promise of a niche and original experience of discovering "treasures 
that were hidden from the public eye." ${ }^{51}$ This tension is sometimes resolved by highlighting the originality of the optical perspectives in which a famous monument is looked at, thus replicating Sorrentino's stylistic attitude of showing well-known architectures from bizarre points of view: "you will continue to the Aventine Hill, Santa Maria del Priorato, to discover the most famous keyhole of Rome, which will give you an unusual and picturesque view of St. Peter's dome." ${ }^{52}$ The rhetoric of the "unusual view" in the tours is also supported by the same choice of locations made by Sorrentino, fascinated by typically Baroque optical illusions, such as the false perspective built by Borromini in Palazzo Spada.

What appears to lack in the design and the presentations of most tours is the invitation to emotional identification with movie characters, and the conception of multisensorial experiences connected to the film, features which frequently characterize movie location tours, as already described. The experiential side of the tours is limited or totally disconnected from the film, relying on a generic Made in Italy brand (e.g., driving a Fiat 500 car) or not (e.g., cycling on an electric bike in the Roman hills). It is obvious that the proposed activities are in some cases extremely far from Jep Gambardella's lifestyle, as we would hardly imagine this elegant dandy on a Fiat 500 or an electric bike. Experiences that could spread from the characters' world could be easily scheduled in a tour and are offered by the same operators within other tours, although never in those related to The Great Beauty. Just to cite the most obvious examples, none of the tours include having an aperitif with Martini or experiencing Rome's cultural life, even if theatre and art performances, as well as exhibitions, all feature in the film. In the only tour which schedules a lunch on a terrace overlooking the Colosseum, the possibility of experiencing the film's atmosphere is not made explicit in the textual presentation..$^{53}$ Another interesting case is that of a tour in Mercedes, for which identification is suggested not with the main character, but with the director himself, inviting the tourist to "be just as inspired as Paolo [Sorrentino] was during the film's production." ${ }^{54}$ This resistance to suggest the identification with an iconic movie character like Jep Gambardella appears in countertrend with the usual way of presenting movie tours, even those proposed by the same tour operators. As an example, the presentation of the Twilight Saga - New Moon (Chris Weitz, 2009) tour of Volterra provided by Italy XP talks to "those who want to relive that romantic atmosphere," while the Spectre (Sam Mendes, 2015) tour in Rome proposed by LoveRome-Tours in Motion invites to "take on the role of Bond" or of the "femme fatale" played by Monica Bellucci, and here the taste of a Martini drink is actually proposed. ${ }^{55}$ The only case out of 20 in which an identification with Jep is explicitly suggested is that of the tour operated by the same LoveRome-Tours in Motion, not by chance specialized in movie tourism. Interestingly, this invitation to identification does not involve the tourist at all. It is the tour guide who is described as "similar to the faded author and journalist who is the lead character," especially because he "knows the skinny on all the spots." The usual meta-tourist reading of the film is thus even more explicit.

There are no invitations to tourists to even experience the very cliché Italian dolce vita, an expression which appears in other tours provided by the same operators. ${ }^{56}$ Interestingly $L a$ dolce vita, intended as the title of Fellini's film, is often used in the presentations of The Great Beauty tours, but there is not a hint of the iconic lifestyle it depicts and which partly inspired Sorrentino. It is quickly mentioned only in relation to 
the tour stop in via Veneto, to increase the prestige of the location through the reference to another famous film shot there. In two occurrences only, Fellini's film is mentioned as an icon of Roman atmosphere, and not by chance, these are the same proposals which highlight the ability of The Great Beauty itself to interpret Rome. Both are provided by operators working at a local scale, largely focusing the textual presentations of their tours on the presumed atmosphere of the city, rather than on the beauty of sights, contrary to other tours. One is the tour provided by LoveRomeTours in Motion, which includes sentences heavily relying on the topos of Roman decadence:

"The Great Beauty" brings bella Rome in its faded yet still fabulous glory to the silver screen. This tour after the film evokes the masterpieces of Federico Fellini with glorious photography and eccentric characters that pass carefree hours in Rome's magnificent and often unknown spots.

The Great Beauty Tour is an ode to the beautiful, decadent Rome from the eponymous film (...).

The other one is provided by an operator called Dearoma Tours (which could be translated into Goddess Rome Tours), with twelve tours in the city "where mankind has often given the best, dealing daily with the divine that nowhere is so human, as in Rome." The Great Beauty is presented with these words, magnifying il dolce far niente:

The Sorrentino masterpiece, Oscar prize winner, has captured on film, the atmosphere that is, since thousands of years, the spell of Rome, a place that enchants and invites to idleness.

This is the meaning of one of the most popular adages of the Eternal City, a sort of mantra often heard among the squares and alleys: "Rome makes you Romano" that absolves and sanctifies the prosopopea, the cynicism and the pleasant indulgence that imprison, for centuries, those who choose to live in Rome.

"The Great Beauty" has imprinted on film these feelings, that already the great Fellini, with great skill, had made universally famous "La Dolce Vita". ${ }^{57}$

Interestingly, the latter text appears identical in Italian language, thus suggesting that 'Romanism' is considered appealing for Italian tourists too. On the contrary, the owner of the operator LoveRome-Tours in Motion stated, during a phone interview, that The Great Beauty tour is offered only to foreigners, because the film is "too full of clichés" for Italians. The operator thus fully adopts the critical views that have mostly characterized the national reception of the film..$^{58}$

\section{Conclusions}

This paper started from the assumption that, within the framework of the consolidated cooperation between the film and tourism industries, tourist marketing is involved in "hermeneutic" acts, proposing specific readings of the film texts to tourists. Actual, as well as virtual, cinematic tourism can be thus considered one of the various contexts of film reception, where the texts produced by the tourist industry work as paratexts.

The Great Beauty appears as a particularly relevant case study because it has been the object of a major debate in the national media, as well as in the academic context, specifically concerning its deliberate purpose of stimulating foreign tourist gaze. However, no survey has been carried out beyond the analysis of the film text, exploring for example its subsequent use by subjects operating in the tourist field. 
What emerges from the present analysis of Great Beauty-related public and private tourist marketing, is specific suggested ways of tourist consumption of Rome and Italy -those of a heritage tourist whose experience heavily relies on the sense of sight. Film tourism in relation to The Great Beauty is understood by the tourism industry as an alternative form of urban heritage tourism, which allows for the creation of new tourist products. The visual eccentricity and the continuous search for visual beauty characterizing Sorrentino's film style are appropriated by tourist marketing texts praising the discovery of hidden locations and unusual perspectives. The authenticity of this tourist experience is identified in the originality of the chosen landmarks and points of view, which differ from those usually visited by mass tourists. This rhetoric is further highlighted in the case of private tours, which transform the search for originality promoted by official tourism marketing into an exaltation of exclusivity. Tourist marketing thus exploits the meta-tourist reading suggested by the movie itself through its portrayal of ideal tourist experiences, especially in the opening scene and in the famous scene of the keys. In the interpretation of tourist marketing, the "traditional brand" of Italy clearly prevails over the "modern brand"-which was also present in the movie, except for the frequent references to Fellini's La dolce vita. Ancient heritage is privileged, and, in some cases, the 'exclusive' heritage linked to aristocracy's past (just like in the most typical English heritage films). To be rejected is the narrative and emotionally troubled universe of the film, which finds little space in the tour descriptions and, seemingly, in the very design of the tourist experience. While movie tours often push towards an identification with movie characters, an immersion within the movie atmosphere and multisensorial stimulation, the experience suggested to the Great Beauty tourists does not entail any of them. Tourists are not even invited to sensual approaches to the Italian imagined "sweet art of life" (dolce vita) nor, in most cases, to "sweet idleness" (il dolce far niente). The suggested experience does not include any participation in contemporary Roman cultural life, even if the latter largely features in the film. The tourist is invited to assume a spectator position and the only action $\mathrm{s} / \mathrm{he}$ is solicited to do is that of gazing and taking photographs. $\mathrm{S} / \mathrm{he}$ is invited to stay in a comfort zone, remaining at a security distance and not permitting a troubling identification with eccentric characters. To be confirmed is the "image of Italy as an enchanted wonderland," which can be gazed at with no risks of being involved in that dangerous fall into decay. This censorship might also reveal an attitude of suspicion towards the "dangerous" side of Rome established in the popular imagination since the 1950s, when "Italy became an image to be consumed" yet "in small doses." ${ }^{59}$ This exciting yet disturbing image, iconized by Fellini's La dolce vita, is exactly the one that is abundantly pillaged by The Great Beauty.

The texts created by tourist marketing thus offer a reading of the movie that easily ignores signs of the present, selecting sights of a great beauty entirely located in the past. The main character's suffered existential path in the reach of fragments of great beauty is easily removed, through simply packaging a collection of those fragments. The marketing of landscape prevails over the understanding of a lived landscape, an understanding that films are usually able to encourage.$^{60}$ This confirms the validity of the Great Beauty reading as heritage film, unmasking its ambivalence in the sense that the "packaging" of the past as heritage, conveyed by the chosen film style, clearly prevails over criticism towards society. Its same disturbing portrayal of present times paradoxically encourages the position of the heritage tourist, yearning for an irremediably lost past. 
The movie tours inspired by The Great Beauty, aimed at well-educated cultural tourists, apparently rely on the trite tourist imaginary of Italy as a premodern country, whose present (including its cultural life, frequently depicted in the film, though in a critical perspective) is not worthy of interest. Film and tourist industries thus effectively converge in proposing this packaged experience, with the additional ruse of promising something original and unique, different from mass tourist experiences, relying on the meta-tourist reading allowed by the movie. What is offered, in most cases, is a very typical sightseeing that does not truly differ from that carried out by the Japanese tourists portrayed (and even ritually 'killed') in the opening scene. This patent contradiction, inherent to the film itself, is thus evidently unmasked by the paratexts produced by the tourist industry, whose "hermeneutic" acts orient physical and virtual cinematic tourist experiences.

\section{BIBLIOGRAPHY}

Agarwal, Sheela and Gareth Shaw. Heritage, Screen and Literary Tourism. Bristol-Blue Ridge Summit: Channel View, 2018.

Bakiewicz, Justyna et al., "Management challenges at film-induced tourism heritage attractions", Tourism Planning \& Development 14, (2017), 548-566.

Balicco, Daniele, Filippo La Porta, and Andrea Minuz. "Paolo Sorrentino, La grande bellezza (2013)" Allegoria 68, (July-December 2013): 205-220.

Beeton, Sue. Film-induced tourism. Clevedon: Channel View, 2005.

Beeton, Sue. "The advance of film tourism", Tourism and Hospitality Planning\&Development 1, (February 2010), 1-6.

Buchmann, Anne, Kevin Moore, and David Fisher, "Experiencing Film Tourism. Authenticity \& Fellowhsip”, Annals of Tourism Research 37, (2010), 229-248.

Connell, Joanne. "Film Tourism-Evolution, progress and prospects", Tourism Management 33, (2012), 1007-1029.

Cooke, Paul and Rob Stone eds. Screening European Heritage. Creating and Consuming History on Film. London: Palgrave Macmillan, 2016.

Couldry, Nick. The Place of Media Power. Pilgrims and Witnesses of the Media Age. Abingdon-New York: Routledge, 2000.

Crespi, Alberto. “Roma, il Grand Tour anche in 500", Bianco e nero 578, (January-April 2014), 28-32.

Crouch, David, Rhona Jackson, and Felix Thompson eds. The Media and the Tourist Imagination. Converging Cultures. Abingdon-New York: Routledge, 2005.

Cucco, Marco and Giuseppe Richeri, Il mercato delle location cinematografiche. Venezia: Marsilio, 2013. 
Cucco, Marco. "Che cosa è un film? La grande bellezza in una prospettiva di economia e politica dei media." In: La trama dei media. Stato, imprese, pubblico nella società dell'informazione, edited by Marco Cucco, 101-119. Roma: Carocci, 2014

D’Angelo, Paolo. “Geofilmica, ovvero: che cosa può fare il cinema per il paesaggio?”, Fata Morgana 6, (September-December 2008), 25-42.

D’Orazio, Costantino. La Roma Segreta del film La Grande Bellezza. Segrate: Sperling\&Kupfer, 2014.

Di Cesare, Francesco and Gloria Rech. Le produzioni cinematografiche, il turismo, il territorio. Roma: Carocci, 2007.

Fadda, Michele and Damiano Garofalo. "The distribution of contemporary Italian Cinema in the United States: the films of Luca Guadagnino and Paolo Sorrentino." Comunicazioni Sociali 3, (September-December 2018): 369-383.

Galt, Rosalind. "Italy's landscapes of loss: historical mourning and the dialectical image in Cinema Paradiso, Mediterraneo and Il Postino." Screen 2, (Summer 2002): 158-173.

Garofalo, Damiano. "La grande bellezza (P. Sorrentino, 2013)", in Cinema made in Italy. la circolazione internazionale dell'audiovisivo italiano, ed. Massimo Scaglioni (Roma: Carocci, 2020), 195-201.

Gazzano, Marco Maria, Stefania Parigi, and Vito Zagarrio eds. Territori del cinema italiano: produzione, diffusione, alfabetizzazione. Udine: Forum, 2013.

Genette, Gérard. Soglie. I dintorni del testo. Torino: Einaudi, 1989.

Gundle, Stephen. "Hollywood Glamour and Mass Consumption in Postwar Italy." Journal of Cold War Studies 3, (Summer 2002): 95-118.

Gunning, Tom. "The Cinema of Attractions: Early Film, its Spectator and the Avant-Garde.” In: Early Cinema: Space - Frame - Narrative, edited by Thomas Elsaesser and Adam Barker, 56-62. London: British Film Institute, 1990.

Higson, Andrew. "Re-presenting the national past: Nostalgia and pastiche in the heritage film." In: Fires were started: British cinema and Thatcherism, edited by Lester Friedman, 109-129. Minneapolis: University of Minnesota Press, 1993.

Higson, Andrew. English Heritage, English Cinema. Costume Drama Since 1980. Oxford: Oxford University Press, 2003.

Hom, Stephanie Malia Hom. The Beautiful Country. Tourism \& the Impossible State of Destination Italy. Toronto-Buffalo-London: University of Toronto Press, 2015.

Karpovich, Angelina. "Theoretical approaches to film-motivated tourism", Tourism and Hospitality Planning\&Development 1, (February 2010), 7-20.

Kim, Sangkyun. “Audience involvement and film tourism experiences: Emotional places, emotional experiences”, Tourism Management 33, (2012), 387-396.

Lavarone, Giulia. Cinema, media e turismo. Esperienze e prospettive teoriche del film-induced tourism. Padova: Padova University Press, 2016.

Lavarone, Giulia. "Cinematic tourism in a time of media convergence: a spatial framework", in The Routledge Companion to Media and Tourism, ed. Maria Månsson et al. (Abingdon-New York: Routledge, 2020), 35-43.

Lee, Christina. “'Have Magic, Will Travel': Tourism and Harry Potter's United (Magical) Kingdom”, Tourist Studies 12, (2012), 52-69 
Leotta, Alfio. Touring the Screen: Tourism and New Zealand Film Geographies (Bristol: Intellect, 2011).

Mancino, Anton Giulio. "Roma: this must be the (product) place(ment)." Cineforum 526, (July 2013): 7-9.

Martin-Jones, David. "Film tourism as heritage tourism: Scotland, diaspora and The Da Vinci Code (2006)", New Review of Film and Television Studies 12, (2014),156-177.

Masoni, Tullio. "Roma in cartolina." Cineforum 526, (July 2013): 10-11.

O'Leary, Alan. “Towards World Heritage Cinema (Starting from the Negative).” In Screening European Heritage. Creating and Consuming History on Film, edited by Paul Cooke and Rob Stone, 63-84. London: Palgrave Macmillan, 2016.

Roberts, Les. "Projecting Place: Location Mapping, Consumption, and Cinematographic Tourism." In The City and the Moving Image: Urban Projections, edited by Richard Koeck and Les Roberts, 183-204. London-New York: Palgrave Macmillan, 2010.

Roberts Les. Film, Mobility and Urban Space. A Cinematic Geography of Liverpool. Liverpool: Liverpool University Press, 2012.

Reijnders, Stijn. Places of the Imagination. Media, Tourism, Culture. Furnham-Burlington: Ashgate, 2011.

Roesch, Stefan. The Experiences of Film Location Tourists. Clevedon: Channel View, 2009

Sbragia, Albert. “The Spectacular Commodification of Rome in Paolo Sorrentino's La grande bellezza", The Italianist 40, (2020), 276-295.

Schofield, Peter. "Cinematographic images of a city. Alternative heritage tourism in Manchester." Tourism Management 5, (August 1996): 333-340.

Torchin, Leshu. "Location, location, location. The destination of the Manhattan TV tour", Tourist Studies 2, (2002), 247-266.

Tzanelli, Rodanthi. The Cinematic Tourist. Explorations in Globalization, Culture and Resistance. Abingdon-New York: Routledge, 2007.

Tzanelli, Rodanthi. "Game of Thrones to game of sites/sights: framing events through cinematic transformations in Northern Ireland." In Event Mobilities: Politics, Place and Performance, edited by Kevin Hannam, Mary Mostafanezhad, and Jillian Rickly, 52-67. Abingdon- New York: Routledge, 2016.

Urry, John and Jonas Larsen. The Tourist Gaze 3.0. London-Thousand Oaks-New Delhi-Singapore: SAGE, 2011.

Winter, Tim. "Angkor Meets Tomb Raider: setting the scene", International Journal of Heritage Studies 8, (2002), 323-336.

\section{NOTES}

1. John Urry and Jonas Larsen, The Tourist Gaze 3.0 (London-Thousand Oaks-New Delhi-Singapore: SAGE, 2011), 116.

2. Rodanthi Tzanelli, The Cinematic Tourist. Explorations in Globalization, Culture and Resistance (Abingdon-New York: Routledge, 2007), 9. 
3. I would like to thank the organizers of the international conference Made in Italy. La circolazione internazionale dell'audiovisivo italiano come prodotto culturale (University of Bologna, June 19-20, 2018), which provided the chance of elaborating the first results of this research.

4. The only exception is a brief text by Alberto Crespi, who just mentions one Great Beauty movie tour offered by a private operator, as well as the book authored by Costantino D'Orazio later discussed: Alberto Crespi, "Roma, il Grand Tour anche in 500", Bianco e nero 578, January/April 2014), 28-32.

5. On the development of interdisciplinary research about film tourism, see: Sue Beeton, "The advance of film tourism", and Angelina Karpovich, "Theoretical approaches to film-motivated tourism", Tourism and Hospitality Planning\&Development 1, (2010), 1-20; Joanne Connell, "Film Tourism-Evolution, progress and prospects", Tourism Management 33, (2012), 1007-1029. As regards the other terms mentioned in the text beside "film tourism", see for example: Sue Beeton, Film-induced tourism Clevedon: Channel View, 2005); Stijn Reijnders, Places of the Imagination. Media, Tourism, Culture (Furnham-Burlington: Ashgate, 2011); Sheela Agarwal and Gareth Shaw, Heritage, Screen and Literary Tourism (Bristol-Blue Ridge Summit: Channel View, 2018); Nick Couldry, The Place of Media Power. Pilgrims and Witnesses of the Media Age (Abingdon-New York: Routledge, 2000).

6. See, among others: Stefan Roesch, The Experiences of Film Location Tourists (Bristol-BuffaloToronto: Channel View, 2009); Anne Buchmann, Kevin Moore, and David Fisher, "Experiencing Film Tourism. Authenticity \& Fellowhsip”, Annals of Tourism Research 37, (2010), 229-248; Reijnders, Places of Imagination; Sangkyun Kim, "Audience involvement and film tourism experiences: Emotional places, emotional experiences", Tourism Management 33, (2012), 387-396.

7. See also, among others: Leshu Torchin, "Location, location, location. The destination of the Manhattan TV tour”, Tourist Studies 2, (2002), 247-266; Christina Lee, “'Have Magic, Will Travel': Tourism and Harry Potter's United (Magical) Kingdom”, Tourist Studies 12, (2012), 52-69; Alfio Leotta, Touring the Screen: Tourism and New Zealand Film Geographies (Bristol: Intellect, 2011).

8. Urry and Larsen, The Tourist Gaze 3.0, 113.

9. As regards the Italian context, see Francesco di Cesare and Gloria Rech, Le produzioni cinematografiche, il turismo, il territorio (Roma: Carocci, 2007).

10. David Crouch, Rhona Jackson, and Felix Thompson, "Introduction: the media and the tourist imagination", in The Media and the Tourist Imagination. Converging Cultures, ed. David Crouch, Rhona Jackson, and Felix Thompson (Abingdon-New York: Routledge, 2005), 2.

11. Tzanelli, The Cinematic Tourist, 3.

12. Les Roberts, Film, Mobility and Urban Space. A Cinematic Geography of Liverpool (Liverpool: Liverpool University Press, 2012), 136-137.

13. Tom Gunning, "The Cinema of Attractions: Early Film, its Spectator and the Avant-Garde", in Early Cinema: Space-Frame-Narrative, eds. Thomas Elsaesser and Adam Barker (London: British Film Institute, 1990), 56-62.

14. Andrew Higson, English Heritage, English Cinema. Costume Drama Since 1980 (Oxford: Oxford University Press, 2003), 37-42. On film tourism and/as heritage tourism, see Peter Schofield, "Cinematographic images of a city. Alternative heritage tourism in Manchester," Tourism Management 5, (August 1996); David Martin-Jones, "Film tourism as heritage tourism: Scotland, diaspora and The Da Vinci Code (2006)", New Review of Film and Television Studies 12, (2014),156-177; Agarwal and Shaw, Heritage, Screen and Literary Tourism. On the challenges posed by film tourism in heritage sites, see for example: Tim Winter, "Angkor Meets Tomb Raider: setting the scene", International Journal of Heritage Studies 8, (2002), 323-336; Justyna Bakiewicz et al., "Management challenges at film-induced tourism heritage attractions", Tourism Planning \& Development 14, (2017), 548-566.

15. di Cesare and Rech, Le produzioni cinematografiche, 46-51.

16. Roberts, Film, Mobility and Urban Space, 144-147. 
17. Rodanthi Tzanelli, "Game of Thrones to game of sites/sights: framing events through cinematic transformations in Northern Ireland," in Event Mobilities: Politics, Place and Performance, ed. Kevin Hannam, Mary Mostafanezhad, and Jillian Rickly (Abingdon- New York: Routledge, 2016).

18. For the concept of paratexts, see Gérard Genette, Soglie. I dintorni del testo (Paris: Seuils, 1987; Torino: Einaudi, 1989).

19. For an understanding of the film tourist experience as one of the multiple contexts of reception of audiovisual texts, see Giulia Lavarone, "Cinematic tourism in a time of media convergence: a spatial framework", in The Routledge Companion to Media and Tourism, ed. Maria Månsson et al. (Abingdon-New York: Routledge, 2020), 35-43.

20. On the development of film tourism research in Italy, see Giulia Lavarone, Cinema, media e turismo. Esperienze e prospettive teoriche del film-induced tourism (Padova: Padova University Press, 2016).

21. Among others: Territori del cinema italiano: produzione, diffusione, alfabetizzazione, ed. Marco Maria Gazzano, Stefania Parigi, and Vito Zagarrio (Udine: Forum, 2013); Marco Cucco and Giuseppe Richeri, Il mercato delle location cinematografiche (Venezia: Marsilio, 2013).

22. Axel Bangert, Paul Cooke and Rob Stone, "Introduction," in Screening European Heritage. Creating and Consuming History on Film, ed. Paul Cooke and Rob Stone (London: Palgrave Macmillan, 2016), xix.

23. Rosalind Galt, "Italy's landscapes of loss: historical mourning and the dialectical image in Cinema Paradiso, Mediterraneo and Il Postino," Screen 2, (Summer 2002).

24. Alan O'Leary, “Towards World Heritage Cinema (Starting from the Negative)," in Cooke and Stone, Screening European Heritage, 66-67.

25. Rosalind Galt and Karl Schoonover, "Untimely Desires, Historical Efflorescence, and Italy in Call me by your name", Italian Culture 37, (2019).

26. Michele Fadda and Damiano Garofalo, "The distribution of contemporary Italian Cinema in the United States: the films of Luca Guadagnino and Paolo Sorrentino," Comunicazioni Sociali 3, (September/December 2018); Damiano Garofalo, "La grande bellezza (P. Sorrentino, 2013)", in Cinema made in Italy. la circolazione internazionale dell'audiovisivo italiano, ed. Massimo Scaglioni (Roma: Carocci, 2020), 195-201. For the total gross of the film, see Box Office Mojo, https:// www.boxofficemojo.com/movies/ <accessed on February 15, 2019>.

27. Among many others, see Albert Sbragia's insightful comparison between Fellini's and Sorrentino's films, where he accuses The Great Beauty of lacking the "urgency" and "historical immediacy" of La dolce vita: Albert Sbragia, "The Spectacular Commodification of Rome in Paolo Sorrentino's La grande bellezza", The Italianist 40, (2020), 276-295. For a survey of the critical reception of The Great Beauty in Italy, France, Switzerland, Great Britain and the United States, see: Garofalo, "La grande bellezza".

28. Anton Giulio Mancino, "Roma: this must be the (product) place(ment)," and Tullio Masoni, "Roma in cartolina," Cineforum 526, (July 2013).

29. On the production of The Great Beauty, see Marco Cucco, "Che cosa è un film? La grande bellezza in una prospettiva di economia e politica dei media," in La trama dei media. Stato, imprese, pubblico nella società dell'informazione, ed. Marco Cucco (Roma: Carocci, 2014).

30. O'Leary, "Towards World Heritage Cinema”, 68.

31. See O'Leary, “Towards World Heritage Cinema", and Daniele Balicco, Filippo La Porta, and Andrea Minuz, "Paolo Sorrentino, La grande bellezza (2013)," Allegoria 68, (July/December 2013): 217-220.

32. Andrew Higson, "Re-presenting the national past: Nostalgia and pastiche in the heritage film," in Fires were started: British cinema and Thatcherism, ed. Lester Friedman (Minneapolis: University of Minnesota Press, 1993), 109.

33. Balicco, La Porta, and Minuz, "Paolo Sorrentino", 217-220. My translation. 
34. Stephen Gundle, Historical Stereotypes and Marketing Cliches in the Foreign Consumption of Italian Cinema, keynote lecture at the International conference Made in Italy. La circolazione internazionale dell'audiovisivo italiano come prodotto culturale (University of Bologna, June 19-20, 2018).

35. O'Leary, “Towards World Heritage Cinema”, 69.

36. Stephen Gundle, "Hollywood Glamour and Mass Consumption in Postwar Italy," Journal of Cold War Studies 3, (Summer 2002): 114.

37. Stephanie Malia Hom, The Beautiful Country. Tourism \& the Impossible State of Destination Italy (Toronto-Buffalo-London: University of Toronto Press, 2015), 52-67; 215.

38. Balicco, La Porta, and Minuz, "Paolo Sorrentino", 207.

39. O'Leary, "Towards World Heritage Cinema", 69.

40. The management of Palazzo Spada, for example, is not allowed to spread data (e-mail received on June 4,2018). The feeling of an increase of visitors was expressed by the Knights of Malta in relation to the famous keyhole on the Aventine Hill (e-mail received on June 6, 2018).

41. Gundle, "Hollywood Glamour".

42. The tour proposals selected in May 2018 are the following: The Great Beauty Tour in Fiat 500 Vintage Car provided by Rome500exp http://www.rome500exp.com/service/the-great-beautytour-in-fiat-500-vintage-car); <accessed on March 22, 2019>; The "Great Beauty" Tour by LoveRome-Tours in Motion https://love-rome.com/tour/grande-bellezza-tour/ <accessed on March 22, 2019>; "The Great Beauty” Tour by ItalyRomeTour https://www.italyrometour.com/thegreat-beauty-rome-tour/ <accessed on March 22, 2019>; The Great Beauty Private Tour by TuscanyAll.com https://www.rome-museum.com/private-tour-great-beauty-rome.php <accessed on March 22, 2019>; The Great Beauty Tour by DeaRomaTours http://www.dearomatours.com/ guided-tour/the-great-beauty/ <accessed on March 22, 2019>; The Great Beauty tour-Rome by Rome and Italy Tourist Services https://www.romeanditaly.com/the-great-beauty-tour-rome/ <accessed on March 22, 2019>; Rome tour of the Great Beauty film locations by TiberLimo https:// www.tiberlimo.com/rome-tours-limo-service/the-great-beauty-rome-movie-locations-tour/ <accessed on March 22, 2019>; "The Great Beauty Tour" by ItalyLuxuryTravel http:// italyluxury.travel/en/itineraries/The_great_beauty_tour.html <accessed on March 22, 2019>; three tours provided by ItalyXP: Group Tour of "The Great Beauty" Movie Locations in Rome https:// italyxp.com/en/rome/tours/great-beauty-group <accessed on March 22, 2019>, Private half day tour of Rome, to discover The Great Beauty movie locations https://italyxp.com/en/rome/tours/greatbeauty-half-day-private <accessed on March 22, 2019> and Exclusive tour of Rome to discover The Great Beauty movie locations https://italyxp.com/en/rome/things-to-do/great-beauty-full-dayprivate <accessed on March 22, 2019>; tours promoted on the marketplaces Musement The Great Beauty electric bike tour https://www.musement.com/uk/rome/the-great-beauty-electric-biketour-2147/ <accessed on March 22, 2019> and Viator Electric bike small-group tour - The Great Beauty https://www.viator.com/tours/Rome/Electric-bike-tour-The-Great-Beauty/d511-8350P1 <accessed on March 22, 2019> and On the traces of: 'The Great Beauty' the movie, in Rome https:// www.viator.com/tours/Rome/On-the-traces-of-The-Great-Beauty-the-movie-in-Rome/ d511-56197P43 <accessed on March 22, 2019>; tours promoted on the Lonely Planet website: HalfDay Private Rome Tour: The Great Beauty https://www.lonelyplanet.com/italy/rome/activities/halfday-private-rome-tour-the-great-beauty/a/pa-act/v-13124P9/359975 <accessed on March 22, 2019> and Roma La grande bellezza Segway Tour https://www.lonelyplanet.com/italy/rome/ activities/roma-la-grande-bellezza-segway-tour/a/pa-act/v-5620P18/359975 < accessed on March 22, 2019>. Four of the webpages consulted on May 2018, presenting the tours provided by Once in Italy (Private The Great Beauty Tour), Guidaly (The Great Beauty tour) and Lookals (The Great Beauty tour), and one tour promoted by Viator (New: The Great Beauty), had disappeared at the time of the last check on March 22, 2019.

43. The phone interview to Ewout Kieckens (Love Rome - Tours in Motion) was led in May 2018. 
44. Here are the links of the Turismo Roma page (http://www.turismoroma.it/cosa-fare/allascoperta-de-la-grande-bellezza-2) and of the VisitLazio (http://portal.visitlazio.com/en/risultatiricerca) page in May 2018. At the last check on March 16, 2019, the VisitLazio page had been renewed with a slightly different text and new images (https://www.visitlazio.com/web/en/ luoghi/the-great-beauty-and-its-locations-in-rome/).

45. Costantino D’Orazio, La Roma Segreta del film La Grande Bellezza (Segrate: Sperling\&Kupfer, 2014).

46. See Schofield, "Cinematographic images of a city".

47. From 2014 to 2017, the page reached between almost 7.500 and 10.000 visualisations per year, with a decreasing trend for the Italian version (from 6.669 in 2014 to 3.481 in 2017) and an increasing one for the English (from 488 to 2.472), Spanish (126 to 1.691), French (87 to 587) and German (63 to 287) versions. As regards The Great Beauty related page on the tourist promotion website of the Lazio Region (VisitLazio), it has reached a smaller public. It was first published in November 2014 and in May 2018 it had been visited only 3.105 times, with a clear predominance of Italian users (83\%). Among other factors, foreign users are obviously more familiar with the tourist brand 'Rome'.

48. I would like to thank Alvise di Giulio (Rome 500 exp) and Ewout Kieckens (Love Rome - Tours in Motion) for providing information in May 2018 through e-mails and phone interviews.

49. The "Great Beauty" Tour by LoveRome-Tours in Motion <accessed on March 22, 2019>.

50. The "Great Beauty" tour provided by Lookals. This webpage, first accessed in May 2018, had disappeared at the time of the last check on March 22, 2019.

51. Private The Great Beauty Tour provided by Once in Italy. This webpage, first accessed in May 2018, had disappeared at the time of the last check on March 22, 2019.

52. The Great Beauty Private Tour provided by TuscanyAll.com <accessed on March 22, 2019>. Emphasis added.

53. The Great Beauty tour-Rome by Rome and Italy Tourist Services <accessed on March 22, 2019>.

54. Half-Day Private Rome Tour: The Great Beauty promoted on the Lonely Planet website <accessed on March 22, 2019>.

55. Private tour of Volterra, following "Twilight" movie locations (https://amp.italyxp.com/en/ tuscany/tours/private-volterra-twilight), James Bond Spectre Tour (https://love-rome.com/tour/ james-bond-spectre-tour/) <both accessed on March 22, 2019>.

56. E.g., the Vespa Vintage Tour provided by Rome500exp http://www.rome500exp.com/service/ vespa-vintage-tour < accessed on March 22, 2019>.

57. The Great Beauty Tour by DeaRomaTours <accessed on March 22, 2019>.

58. Another operator, on the contrary, seems to be more confident on the appreciation of the film by Italian tourists rather than foreign ones. On its webpage, the textual presentations of the tour in Italian and in English largely differ. The Italian version contains references to specific film scenes and locations, while the English one just mentions the title of the film. Despite the tour name, its English presentation displays other cinematographic references, such as Roman Holiday (William Wyler, 1953), a film which also "lends" the tour stop at the Mouth of Truth, a location which does not feature in The Great Beauty. There is also a reference to famous American actors like Johnny Depp, who have driven Fiat 500s, the car used for the tour, in their films. The Great Beauty is maybe seen as too much of an art house film to be appreciated by non-Italian people, and it thus needs to be supported with other consolidated elements of the Italian brand, like Fiat 500, or with references to much more popular American movies and stars. See: The Great Beauty Tour in Fiat 500 Vintage Car and La Grande Bellezza tour in Fiat 500 d'epoca https:// www.rome500exp.com/it/service/la-grande-bellezza-tour-in-fiat-500-depoca <both accessed on March 22, 2019>.

59. Gundle, "Hollywood Glamour", 114. 
60. Paolo D'Angelo, “Geofilmica, ovvero: che cosa può fare il cinema per il paesaggio?", Fata Morgana 6, (September/December 2008), 25-42.

\section{ABSTRACTS}

This paper explores how Italian heritage is presented through the narrative and stylistic features of the Academy Award winner film The Great Beauty by Paolo Sorrentino (2013), and which 'Italianness' is therein identified by the tourism industry. After tracing some arguments of the national debate on the film, I analyze the official online tourism marketing pages set up by public bodies and the movie tour proposals offered by tour operators on their websites. This shows that film tourism in relation to The Great Beauty is understood as an alternative form of urban heritage tourism. The authenticity of this tourist experience is identified in the originality of the chosen landmarks and points of view, thus adopting the meta-tourist reading suggested by the film. To be rejected is its narrative and emotional troubled universe, which finds little space in the design of the experience, in countertrend with most movie tour proposals.

\section{INDEX}

Keywords: film tourism, heritage film, heritage tourism, Italian cinema, Paolo Sorrentino

\section{AUTHOR}

\section{GIULIA LAVARONE}

Giulia Lavarone is a research fellow in film studies at the University of Padua (Italy). In 2010 she got a Ph.D. degree at the same University with a study abroad period at the Université Paris I Panthéon Sorbonne. Her thesis focused on French films' representation of the widespread urban renewals in Paris during the Fifties and Sixties. In 2014-2015 and 2016-2018 she has been undertaking postdoctoral research at Padua University within two interdisciplinary projects on film-induced tourism. In 2016 she published the book Cinema, media e turismo (Padova University Press). She has authored several scholarly articles on films by Jacques Rivette, Agnès Varda, Matteo Garrone, Quentin Tarantino and many others, focusing on intertextuality and the relationship between cinema and other arts, on cinema and the city and on film-induced tourism. 